Louisiana State University

LSU Digital Commons

Faculty Publications

Department of Biological Sciences

$10-1-2018$

\title{
Fertilization influences the nutrient acquisition strategy of a nomadic vine in a lowland tropical forest understory
}

\author{
Carrie L. Woods \\ University of Puget Sound \\ Saara J. DeWalt \\ Clemson University \\ Catherine L. Cardelús \\ Colgate University \\ Kyle E. Harms \\ Louisiana State University \\ Joseph B. Yavitt \\ Cornell University
}

See next page for additional authors

Follow this and additional works at: https://digitalcommons.Isu.edu/biosci_pubs

\section{Recommended Citation}

Woods, C., DeWalt, S., Cardelús, C., Harms, K., Yavitt, J., \& Wright, S. (2018). Fertilization influences the nutrient acquisition strategy of a nomadic vine in a lowland tropical forest understory. Plant and Soil, 431 (1-2), 389-399. https://doi.org/10.1007/s11104-018-3772-9

This Article is brought to you for free and open access by the Department of Biological Sciences at LSU Digital Commons. It has been accepted for inclusion in Faculty Publications by an authorized administrator of LSU Digital Commons. For more information, please contact ir@lsu.edu. 
Authors

Carrie L. Woods, Saara J. DeWalt, Catherine L. Cardelús, Kyle E. Harms, Joseph B. Yavitt, and S. Joseph Wright 


\title{
Fertilization influences the nutrient acquisition strategy of a nomadic vine in a lowland tropical forest understory
}

\author{
Carrie L. Woods (iD - Saara J. DeWalt • \\ Catherine L. Cardelús • Kyle E. Harms • \\ Joseph B. Yavitt • S. Joseph Wright
}

Received: 31 May 2018 / Accepted: 1 August 2018/Published online: 11 August 2018

(C) Springer Nature Switzerland AG 2018

\begin{abstract}
Aims Tropical tree and lianas in the understory are limited by soil nutrients despite growing in extremely low light. It is not known if nomadic vines are also limited by nutrients in low light conditions.

Methods We measured differences in root architecture and mycorrhizal colonization, and leaf nutrients of a nomadic vine, Philodendron fragrantissimum (Araceae), in nitrogen $(\mathrm{N})$ and phosphorus $(\mathrm{P})$ fertilization plots in a lowland tropical moist forest in central
\end{abstract}

Responsible Editor: Hans Lambers.

C. L. Woods $(\bowtie)$

Biology Department, University of Puget Sound, 1500 N. Warner Ave, Tacoma, WA 98416-1088, USA

e-mail: cwoods@pugetsound.edu

\section{S. J. DeWalt}

Department of Biological Sciences, Clemson University, 132

Long Hall, Clemson, SC 29634, USA

\section{L. Cardelús}

Department of Biology, Colgate University, 13 Oak Drive,

Hamilton, NY 13346, USA

\section{K. E. Harms}

Department of Biological Sciences, Louisiana State University, 202 Life Sciences Building, Baton Rouge, LA 70803, USA

J. B. Yavitt

Department of Natural Resources, Cornell University, 118 Fernow Hall, Ithaca, NY 14853, USA

S. J. Wright

Smithsonian Tropical Research Institute, P.O. Box 0843-03092, Balboa, Ancon, Panama City, Republic of Panama
Panama to measure potential nutrient limitation.

Results Relative to plants in control plots, leaf $\mathrm{P}$ concentration was $54 \%$ higher and leaf $\mathrm{N}$ concentration was $10 \%$ higher for plants in the P- and N-addition treatments, respectively. The N:P of leaves suggested Plimitation in the $\mathrm{N}$-addition treatment and the control but not in the P-addition treatment. Root branching was highest in the $\mathrm{P}$-addition treatment, and $\mathrm{P}$-addition reduced mycorrhizal colonization.

Conclusions The large effect of $\mathrm{P}$ fertilization suggests that, like many tropical plants, $P$. fragrantissimum has the potential to be P-limited. Although further study is needed, we suggest that nomadic vines be added to the growth forms that respond to nutrient addition in the forest understory and conclude that nutrient-limitation seems like the rule rather than the exception in the lightlimited understory.

Keywords Barro Colorado Nature Monument . Fertilization · Nitrogen $\cdot$ Nomadic vine $\cdot$ Philodendron fragrantissimum $\cdot$ Phosphorus

\section{Introduction}

The availability of light is thought to be the most limiting resource to plants in the understory of tropical forests (Coomes and Grubb 2000). The severity of light limitation in the understory $(0.4-3.8 \%$ transmission, Chazdon and Fetcher 1984) is thought to prevent plants from responding to increases in other resources, such as soil nutrients (Hättenschwiler 2002), in accord with 
Liebig's law of the minimum that only one resource can be limiting at any time. However, fertilization studies have shown that terrestrial plant growth and reproduction are often limited by the availability of nutrients (Tripler et al. 2006; Elser et al. 2007; LeBauer and Treseder 2008). Some tropical tree and liana seedlings have responded to added nutrients by increasing their growth even when growing in forest understory conditions (<1\% full sunlight) (Burslem et al. 1996; Vitousek and Farrington 1997; Hättenschwiler 2002; Santiago et al. 2012). Leaf $\mathrm{N}$ and $\mathrm{P}$ stoichiometry can also indicate nutrient limitation (Güsewell 2004; Elser et al. 2007). N:P ratios have been found to correlate negatively with growth rate across terrestrial and aquatic primary producers (Nielsen et al. 1996), and N:P ratios of understory tree leaves $>1$ yr. old can indicate changed soil nutrient availability with fertilization in tropical forests (Mo et al. 2015). Thus, plants in the understory of tropical forests may be limited by multiple resources as measured by their changes in growth, reproduction, or leaf stoichiometry (Bloom et al. 1985).

Nomadic vines germinate on the forest floor, climb into the canopy on a host tree in search of light, and eventually lose parts of their stem while maintaining a terrestrial root connection as they ascend a host tree (Moffett 2000; Zotz 2013). Nomadic vines differ from lianas, which are woody vines that maintain their stem and root connection as they ascend their host tree (Schnitzer and Bongers 2002). Many aroids (Araceae) are nomadic vines including many species in the genera Philodendron and Monstera (Williams-Linera and Lawton 1995) as well as some ferns in the Hymenophyllaceae (Dubuisson et al. 2011). Nomadic vines are an important and unique component of tropical forests; they compose $72 \%$ of individuals and $35 \%$ of vascular epiphyte species in lowland moist forests in Panama (Woods and DeWalt 2013), yet little is known about how nomadic vines respond to variation in soil nutrients. Their responses to patches of higher nutrient availability are likely larger than in other tropical plant groups because of their highly plastic growth form; nomadic vines exhibit remarkable flexibility in response to light availability (Strong and Ray 1975; Balcázar-Vargas et al. 2012). In fact, the dim light of the understory is thought to be the evolutionary driver of the nomadic life history (Putz and Holbrook 1986). Monstera gigantean (Araceae), for example, finds hosts by growing towards the darkness of a tree silhouette (Strong and Ray 1975), and Heteropsis spp. (Araceae) have a highly flexible and random searching strategy to find a host tree (Balcázar-Vargas et al. 2012). For nomadic vines in the understory, the availability of soil nutrients might elicit a plastic response to acquire nutrients just as the availability of light elicits plastic shoot responses (Strong and Ray 1975; Balcázar-Vargas et al. 2012).

One way in which nomadic vines might exhibit highly plastic responses to heterogeneous supplies of nutrients in the soil is in their root systems. Plant roots use chemotropism to detect patches of nutrients in heterogeneous soils and will often have a high degree of lateral root proliferation in patches of high nutrient supply (Drew and Saker 1978; van Vuuren et al. 1996; Wang et al. 2006). Smaller diameter roots have a greater uptake capacity than larger roots (Eissenstat and Yanai 1997), and the number of small and fine roots are often greater in patches of high nutrient availability, which increases uptake of limiting nutrients (Drew and Saker 1978; Robinson and Rorison 1983; Fitter 1985; Farley and Fitter 1999). Root proliferation, root branching, and increases in the number of small roots should be highest in patches where $\mathrm{P}$ availability is high because $\mathrm{P}$ forms complexes with cations and readily adsorbs to soil (Chapin III 1980; Lambers et al. 2008). In lowland tropical forests in southern China, for example, fineroot biomass increased with P-addition (Zhu et al. 2013). Root proliferation is less important for acquisition of highly mobile nutrients such as nitrogen in the form of nitrate $\left(\mathrm{NO}_{3}{ }^{-}\right)$because mobile nutrients will move down the diffusion gradient towards the rhizosphere created by root uptake (Chapin III 1980; Lambers et al. 2008; Marschner 2012). Plants may invest in mycorrhizal associations in response to poor soil nutrient availability, particularly of P (Chapin III 1980; Marschner and Dell 1994; Clark and Zeto 2000; Fitter et al. 2002). Plant root proliferation may be unnecessary when roots are colonized by mycorrhizal fungi because mycorrhizal hyphae are less expensive to the plant than growing roots (Fitter 1991; Tibbet 2000). Thus, plant roots may indicate variations in a plant's response to increased nutrient addition, even in light-limited areas.

In this study, we examined variation in nutrient acquisition by one species of a nomadic vine in the shaded understory of lowland moist tropical forest in central Panama. We used a long-running $\mathrm{N}$ and $\mathrm{P}$ fertilization experiment to test several predictions about how Philodendron fragrantissimum (Hook.) G. Don. (Araceae) would respond to nutrient addition even while being light-limited. We predicted: 
1. P. fragrantissimum would, like many trees, show higher leaf nutrient concentrations in plots where $\mathrm{N}$ and $\mathrm{P}$ have been added for the past 11 years as a result of greater nutrient availability.

2. P. fragrantissimum would show similar nutrient acquisition strategies as trees including greater root-branching and a greater proportion of small roots in the $\mathrm{P}$-addition plots but less rootbranching in the $\mathrm{N}$-addition plots compared to controls.

3. Mycorrhizal colonization would be negatively associated with greater leaf $\mathrm{P}$ content, irrespective of treatment, because plants would only invest in mycorrhizal fungi if they were nutrient limited, and mycorrhizae are effective at scavenging P (Clark and Zeto 2000; Fitter et al. 2002; Treseder 2004).

While we did not measure growth or biomass of plants to directly test if the plants were nutrient limited, we used static variables, such as leaf nutrient concentrations, leaf stoichiometry, root structure, and mycorrhizal colonization that measure the potential response of P. fragrantissimum to fertilization.

\section{Materials and methods}

Study site The Gigante Fertilization Plots (GFP) are located in a 38.4 ha plot $\left(9^{\circ} 06^{\prime} 31^{\prime \prime} \mathrm{N}, 79^{\circ} 50^{\prime} 37^{\prime \prime} \mathrm{W}\right)$ in the Barro Colorado Nature Monument in the Republic of Panama (Yavitt et al. 2009; Yavitt et al. 2011; Wright et al. 2011). Tropical moist forests cover the BCNM. Annual rainfall averages approximately $2600 \mathrm{~mm}$, with just $10 \%$ falling during a 4-months dry season between December and April (Holdridge and Budowski 1956). The tree composition and stature at this site is indicative of very old (>200 yr) secondary forest (Wright et al. 2011). The mean $( \pm$ SE) canopy openness of the understory in the GFP is $4.9 \%( \pm 0.7 \%)$ (Santiago et al. 2012). Soils in the GFP transition from Oxisols (Typic Hapludox in Soil Taxonomy; Soil Staff Survey 1999) in the upper northeast corner to poorly drained Inceptisols (Aeric Epiaquepts) in the southwest corner (B. L. Turner, unpublished data). The underlying bedrock is Miocene basalt (Stewart et al. 1980).

Plant-available soil nutrient concentrations in the control plots are infertile relative to most forest soils in central Panama as the concentration of exchangeable phosphate and potassium are both quite low $(<1 \mathrm{mg} \mathrm{P}$ $\mathrm{kg}^{-1}$ and $103 \mathrm{mg} \mathrm{K} \mathrm{kg}{ }^{-1}$; Condit et al. 2013; Turner et al. 2013). The addition of $\mathrm{N}$ and $\mathrm{P}$ increased the concentrations of plant available forms of $\mathrm{N}$ and $\mathrm{P}$ in the soil; each added nutrient increased plant tissue concentrations of that nutrient; $\mathrm{K}$ addition decreased fine root biomass and increased rates of seedling growth, fine root turnover and decomposition; $\mathrm{P}$ addition increased fine litter production and decomposition; combined $\mathrm{N}$ and $\mathrm{P}$ addition increased seedling growth rates; and combined $\mathrm{N}$ and $\mathrm{K}$ addition ameliorated declining tree growth rates (Kaspari et al. 2008; Yavitt et al. 2011; Wright et al. 2011; Santiago et al. 2012; Turner et al. 2013; Mayor et al. 2014). After 15 years of fertilization, tree growth rates had not responded to fertilization, possibly because $47 \%$ of the individual trees in the GFP are from species strongly associated with P-poor soils (Wright et al. 2018), and species adapted to low resource soils often have a limited potential to respond to increases in resources (Coley et al. 1985). However, after 15 years of fertilization, there was still an increase in foliar nutrients, an increase in fine litter production, and an increase in litter nutrient concentration with $\mathrm{N}$ and $\mathrm{P}$ addition. Thus, nutrients limit plants in these tropical soils.

For our study, we used three replicate plots of each of three treatments: control (no nutrient addition), nitrogen ( $\mathrm{N}$ addition only), and phosphorus ( $\mathrm{P}$ addition only). These plots were a subset of the plots in the Gigante Fertilization Project that included four replicate plots of a full factorial nitrogen-phosphorus-potassium (NPK) experiment (Yavitt et al. 2009; Yavitt et al. 2011; Wright et al. 2011). We only sampled individuals from three replicate plots of $\mathrm{N}$ and $\mathrm{P}$ (rather than all of the available fertilization plots) because $P$. fragrantissimum was found only in these plots.

Beginning in 1998, fertilizer was added in each plot by hand in four equal doses in each wet season with 6 8 weeks between applications. Nitrogen was added as coated urea $\left(\left(\mathrm{NH}_{4}\right)_{2} \mathrm{CO}\right)$ at a dose of $125 \mathrm{~kg} \mathrm{ha}^{-1} \mathrm{yr}^{-1}$, and phosphorus was added as triple superphosphate $\left(\mathrm{Ca}\left(\mathrm{H}_{2} \mathrm{PO}_{4}\right)_{2} \mathrm{H}_{2} \mathrm{O}\right)$ at $50 \mathrm{~kg} \mathrm{ha}^{-1} \mathrm{yr}^{-1}$ (Yavitt et al. 2011; Wright et al. 2011). The $\mathrm{N}$ and $\mathrm{P}$ additions equal 69 and $470 \%$, respectively, of annual inputs from fine litter at a nearby site (3 km away; Yavitt et al. 2004). Adding a high concentration of $\mathrm{P}$ relative to litter inputs is standard in tropical nutrient-addition experiments (Tanner et al. 1992; Mirmanto et al. 1999) because many soils, including those in the GFP, sequester large 
amounts of added $\mathrm{P}$ in forms that are inaccessible to plants (Yavitt et al. 2011; Mirabello et al. 2013).

Soil samples were collected from every plot in the factorial experiment monthly for 1 year from November 2006 to November 2007 (Turner et al. 2013). Added N significantly increased concentrations of soil $\mathrm{K}_{2} \mathrm{SO}_{4}$-extractable $\mathrm{NO}_{3}$ relative to control plots by 2 -fold and acidified the soil by $0.8 \mathrm{pH}$ units (Yavitt et al. 2011; Turner et al. 2013); the average available $\mathrm{NO}_{3}$ was $8.19 \pm 1.18 \mathrm{mg} \mathrm{N} \mathrm{kg}^{-1}$ in control plots and $18.2 \pm$ $1.22 \mathrm{mg} \mathrm{N} \mathrm{kg}^{-1}$ in $\mathrm{N}$-addition plots (Turner et al. 2013). Added $P$ increased concentrations of Mehlich$\mathrm{PO}_{4}$, plant-available inorganic and organic $\mathrm{P}$, and inorganic and organic $\mathrm{P}$ bound to iron and aluminum (Yavitt et al. 2011; Turner et al. 2013); average Mehlich P concentration was $0.57 \pm 0.02 \mathrm{mg} \mathrm{P} \mathrm{kg}^{-1}$ in control plots and $16.72 \pm 1.87 \mathrm{mg} \mathrm{P} \mathrm{kg}^{-1}$ in P-addition plots (Turner et al. 2013). The increase in organic $P$ indicates that some of the added $\mathrm{P}$ was incorporated into plant material and returned to the soil through dead plant material, thereby contributing to plant-soil cycling (Yavitt et al. 2011).

Philodendron fragrantissimum (Hook.) G. Don was the most common nomadic vine in the GFP and was the only nomadic vine abundant enough in the plots to enable replication. From each plot, we sampled five replicate individuals of $P$. fragrantissimum. (Araceae; hereafter Philodendron) in July 2009, 11 years after the fertilization experiment began. For each individual, we sampled a fully expanded leaf without evidence of epiphylls or damage and one well-developed root. For the root sample, we followed one of the main roots originating from the plant into the terrestrial soil and dug up the soil around the root so as not to damage the root and its lateral roots before collection. To control for potential effects of age and size of plants as well as environmental variation, all individual plants were in the understory, were of similar size, and were collected from within 4-5 $\mathrm{m}$ from the forest floor on a host tree in similar forest (e.g., no samples were taken from plants next to a gap, trail or stream). Leaf samples were dried and shipped to Colgate University for nutrient analyses. Root samples were stored in 95\% ethanol and shipped to Clemson University for root analyses.

Leaf and root analyses Leaf samples were ground using a Wiley Mill (Thomas Scientific, Swedesboro, NJ) and passed through a \#40 screen. Total carbon (C) and $\mathrm{N}$ were determined on a Costech Analytical Elemental Analyzer (Valencia, California) in the Geology
Department at Colgate University. Total P was measured using an ash digestion (Jones and Case 1996) followed by colorimetric determination of orthophosphate using the microscale malachite green method (D'Angelo et al. 2001). We calculated the carbon-tonitrogen ratio $(\mathrm{C}: \mathrm{N})$, carbon-to-phosphorus ratio $(\mathrm{C}: \mathrm{P})$, and nitrogen-to-phosphorus ratio (N:P). These ratios are commonly used to assess particular nutrient limitations. For example, in epiphytic tank bromeliads, N:P ratios $>12$ indicate $\mathrm{P}$ limitation (Wanek and Zotz 2011) and $\mathrm{N}: \mathrm{P}$ ratios $>20$ can indicate P-limited biomass production (Güsewell 2004).

Root branching and the proportion of total root length comprised of fine roots (i.e., $<0.6 \mathrm{~mm}$ diameter) were measured using WinRHIZO ver.2003b (Regent Instruments, Quebec, Canada) (Arsenault et al. 1995). Root samples were placed in a Plexiglas tray in 3-4 $\mathrm{mm}$ of water, untangled to minimize root-overlap, and scanned. Our size limit for fine roots was similar to other studies ( $<0.5 \mathrm{~mm}$, Jackson et al. 1990; <2.0 mm, Yavitt et al. 2011), and was defined as those that are most likely involved in nutrient absorption than nutrient transport rather than just being defined by diameter alone (McCormack et al. 2015).

Three subsamples of each root were rinsed in DI water and mounted in biopsy cassettes to score for mycorrhizal colonization. Roots were cleared in $10 \%$ potassium hydroxide for $72-96 \mathrm{~h}$ at $70{ }^{\circ} \mathrm{C}$ and then rinsed three times with deionized water. Roots were then stained with trypan blue (Koske and Gemma 1989) for $20 \mathrm{~min}$, destained in a $50 \%$ glycerol (v: v) solution for $48 \mathrm{~h}$, and mounted on slides. The degree of colonization of roots by mycorrhizal hyphae, vesicles and arbuscules was estimated using the magnified intersection method at 200× magnification (McGonigle et al. 1990). Fifty intersections were used per slide. Colonization rates were calculated as the number of positive intersections of each fungal material divided by the total number of intersections per slide (i.e. 50). Colonization rates for each root sample were calculated as the average of each of three slides.

Statistical analyses We used analyses of variance (ANOVA) followed by Tukey HSD tests to examine differences in leaf nutrient concentration per unit mass (N, P, C:N, C:P, and N:P), root architecture (root tips/ unit length and proportion of fine roots), and \% root colonization by mycorrhizal fungi (using hyphal, vesicular, and arbuscular values separately) among the 
control and $\mathrm{N}$ - and P-fertilized plots. For the leaf $\mathrm{P}$ concentration analyses (leaf $\mathrm{P}, \mathrm{N}: \mathrm{P}$, and $\mathrm{C}: \mathrm{P}$ ), two data points were removed as outliers to reach normality assumptions. For the root architecture analyses, three root samples were destroyed in the lab and, therefore, unusable in the WinRhizo analysis. We used correlation to examine the relationship between $\%$ mycorrhizal colonization and leaf nutrient concentration per unit mass (N, P, C:N, C:P, and $\mathrm{N}: \mathrm{P})$. We used the aov function in the stats package in R v.3.0.1 for all statistical analyses (R Development Core Team 2009).

\section{Results}

Philodendron had significantly higher leaf $\mathrm{N}$ concentration $\left(F_{2,44}=8.02, P=0.001\right)$ and higher leaf $\mathrm{P}$ concentration $\left(F_{2,42}=15.65, P<0.001\right)$ in $\mathrm{N}$ - and P-addition treatments relative to the control treatment, respectively (Fig. 1). Leaf $\mathrm{N}$ concentration was $10 \%$ greater in the $\mathrm{N}$ addition treatment than the control, and leaf $\mathrm{P}$ concentration was $54 \%$ greater in the $\mathrm{P}$-addition treatment than the control (Fig. 1). Leaf C:N was significantly higher in the $\mathrm{P}$-addition treatment relative to the $\mathrm{N}$-addition treatment but neither were significantly different from the control (Fig. 2a; $F_{2,44}=7.74, P=0.001$ ). Fertilization treatment significantly influenced leaf $\mathrm{C}: \mathrm{P}\left(F_{2,42}=7.65\right.$, $P=0.002)$ and leaf N:P $\left(F_{2,42}=9.41, P<0.001\right)$; both leaf $\mathrm{C}: \mathrm{P}$ and leaf $\mathrm{N}: \mathrm{P}$ were lower in the P-addition treatments relative to the $\mathrm{N}$-addition treatments and the control (Fig. 2). Leaf N:P in the P-addition treatment $(10.8 \pm 0.4)$ was $104 \%$ lower than in the $\mathrm{N}$-addition treatment $(22.1 \pm 2.4)$ and $86 \%$ lower than in the control (20.1 \pm 2.3 ; Fig. 2).

Root branching was significantly affected by fertilization treatment as the number of root tips/length (Fig. 3a, $F_{2,41}=4.24, P=0.02$ ) and the proportion of fine roots $(<0.6 \mathrm{~mm})$ (Fig. $\left.3 b, F_{2,41}=3.96, P=0.03\right)$ were higher in the P-addition treatments compared to the control. Root branching and the proportion of fine roots were not influenced by $\mathrm{N}$ fertilization (Fig. 3).

Using hyphae as a measure of mycorrhizal colonization, there were no significant differences in \% mycorrhizal colonization of Philodendron roots across fertilization treatments $\left(F_{2,44}=0.58, P=0.6\right)$, nor did it vary with $\mathrm{N}$ concentration of leaves (Fig. $4 \mathrm{a} ; r=0.11$, $\mathrm{df}=$ $45, P=0.5)$ or leaf $\mathrm{C}: \mathrm{N}(r=-0.08, \mathrm{df}=45, P=0.6)$. However, \% mycorrhizal colonization was significantly negatively correlated with leaf $\mathrm{P}$ concentration (Fig. $4 \mathrm{~b}$; $r=-0.30, \mathrm{df}=43, P=0.05)$ and positively correlated with leaf C:P $(r=0.35, \mathrm{df}=43, P=0.02)$ and leaf $\mathrm{N}: \mathrm{P}$ ( $r=0.32, \mathrm{df}=43, P=0.03)$. The results for vesicular and arbuscular colonization were similar to those for hyphal colonization and therefore are not shown.

\section{Discussion}

Differences in root morphology and mycorrhizal colonization among treatments suggest that the nutrient acquisition strategy of the nomadic vine Philodendron fragrantissimum differs with nutrient availability even in the shaded conditions of the tropical forest understory. Leaf nutrient concentration also showed a response to fertilization. Leaf $\mathrm{N}$ concentration was
Fig. 1 Mean $( \pm$ SE) foliar nutrient concentration per unit mass $\left(\mathrm{N}_{\text {mass }}\right.$ and $\mathrm{P}_{\text {mass }}$ ) of Philodendron fragrantissimum from control and fertilization plots. Five individual plants were collected from three replicate unfertilized, control plots and plots fertilized with nitrogen and phosphorus in the Gigante Fertilization Project in central Panama. Different letters denote significant differences among treatments according to a Tukey's HSD test $(P<0.05)$

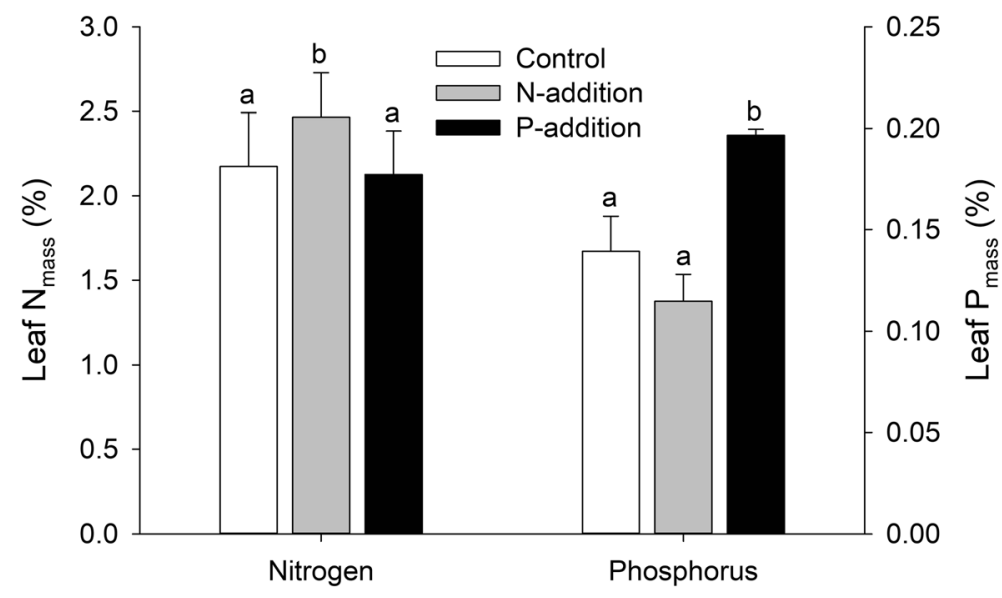



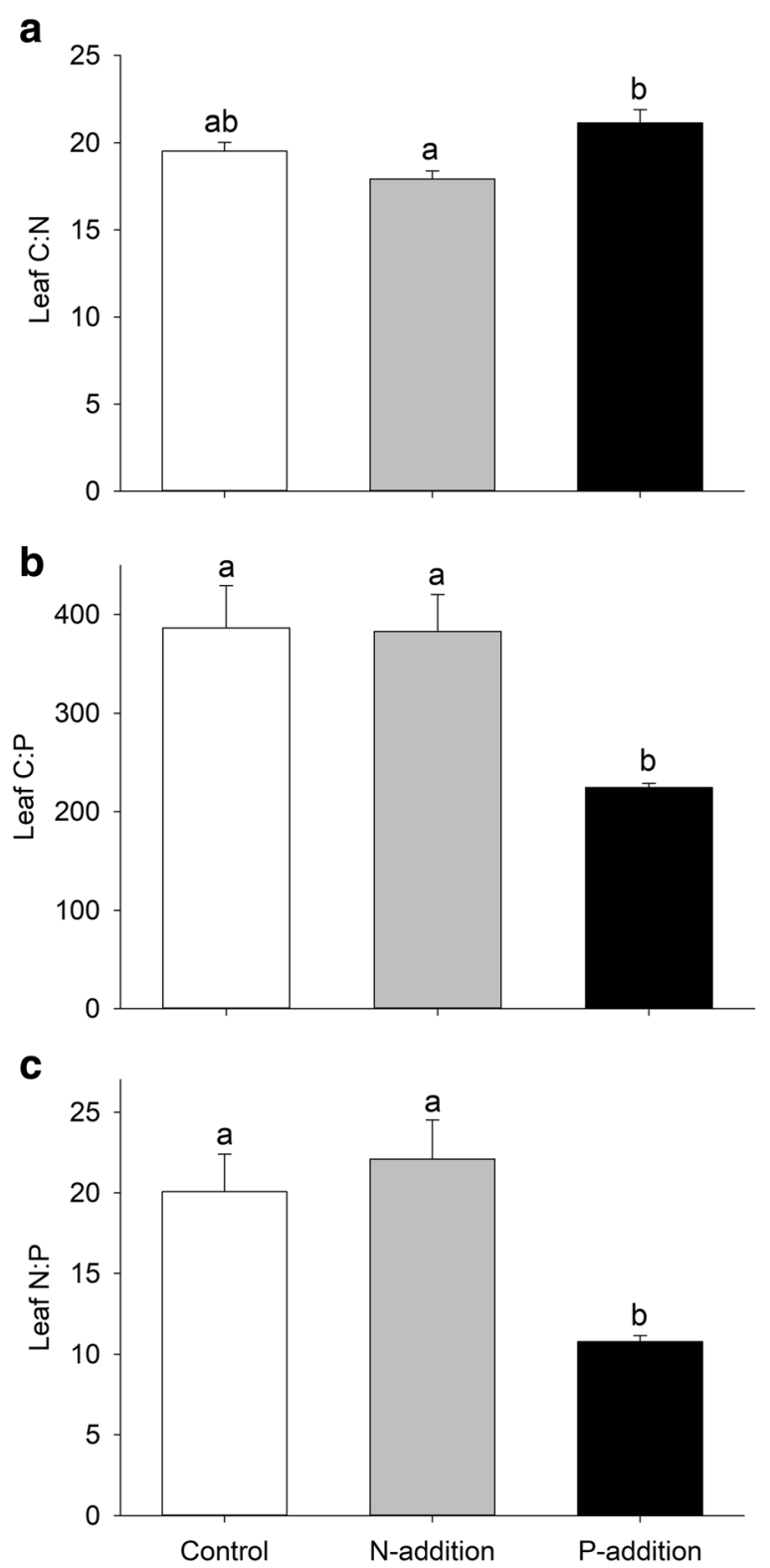

Fig. 2 Mean $( \pm \mathrm{SE})$ foliar stoichiometry of Philodendron fragrantissimum from control and fertilization plots $(\mathrm{C}: \mathrm{N}$ in (a), $\mathrm{C}: \mathrm{P}$ in (b), and $\mathrm{N}: \mathrm{P}$ in (c)). Five individual plants were collected from three replicate unfertilized, control plots and plots fertilized with nitrogen and phosphorus in the Gigante Fertilization Project in central Panama. Different letters denote significant differences among treatments according to a Tukey's HSD test $(P<0.05)$

$10 \%$ higher and leaf $\mathrm{P}$ concentration was $54 \%$ higher in the plots fertilized with $\mathrm{N}$ and $\mathrm{P}$, respectively, than the control treatment. Furthermore, leaf $\mathrm{N}: \mathrm{P}$ in the Naddition and control plots was indicative of $\mathrm{P}$ limitation $(>20)$ while leaf $\mathrm{N}: \mathrm{P}$ in the P-addition treatment was not $(\sim 10$; Güsewell 2004; Elser et al. 2007; a
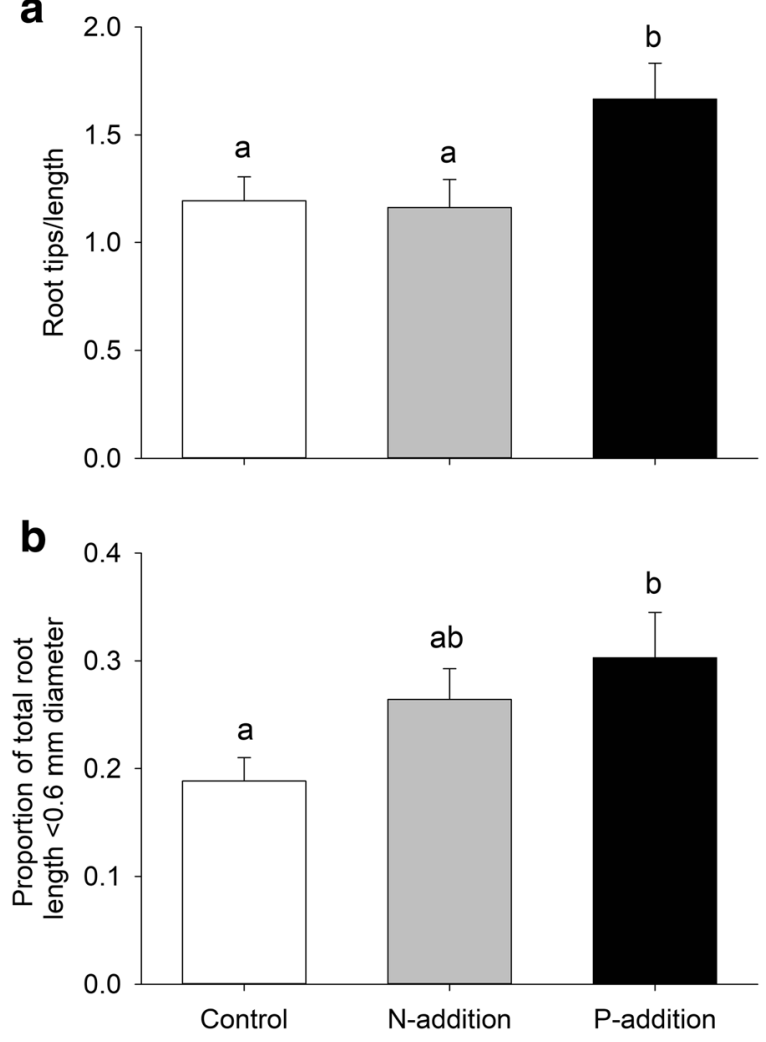

Fig. 3 Mean $( \pm \mathrm{SE})$ root branching (root tips / length of root; (a)) and the proportion of small roots $(<0.6 \mathrm{~mm}$ diameter; (b)) of Philodendron fragrantissimum from control and fertilization plots. Five individual plants were collected from three replicate unfertilized, control plots and plots fertilized with nitrogen and phosphorus in the Gigante Fertilization Project in central Panama. Different letters denote significant differences among treatments according to a Tukey's HSD test $(P<0.05)$

Wanek and Zotz 2011). These results are similar to those found for trees and tree seedlings in seven different tropical fertilization experiments whereby foliar nutrients of at least one nutrient increased significantly with nutrient addition (Wright et al. 2018), and $\mathrm{N}: \mathrm{P}$ ratios of understory tree leaves varied with soil nutrient availability (Mo et al. 2015). A nomadic vine, therefore, exhibited a similar response to nutrient addition as tropical trees and tropical tree seedlings growing either in high light (e.g., trees) or in the deeply shaded understory (e.g., tree seedlings) (Mo et al. 2015; Wright et al. 2018). While we did not measure growth or biomass of Philodendron, our static measures suggest that Philodendron has the potential to be nutrient-limited. Thus, limitation by multiple resources seems to be the case for several plant lifeforms. 

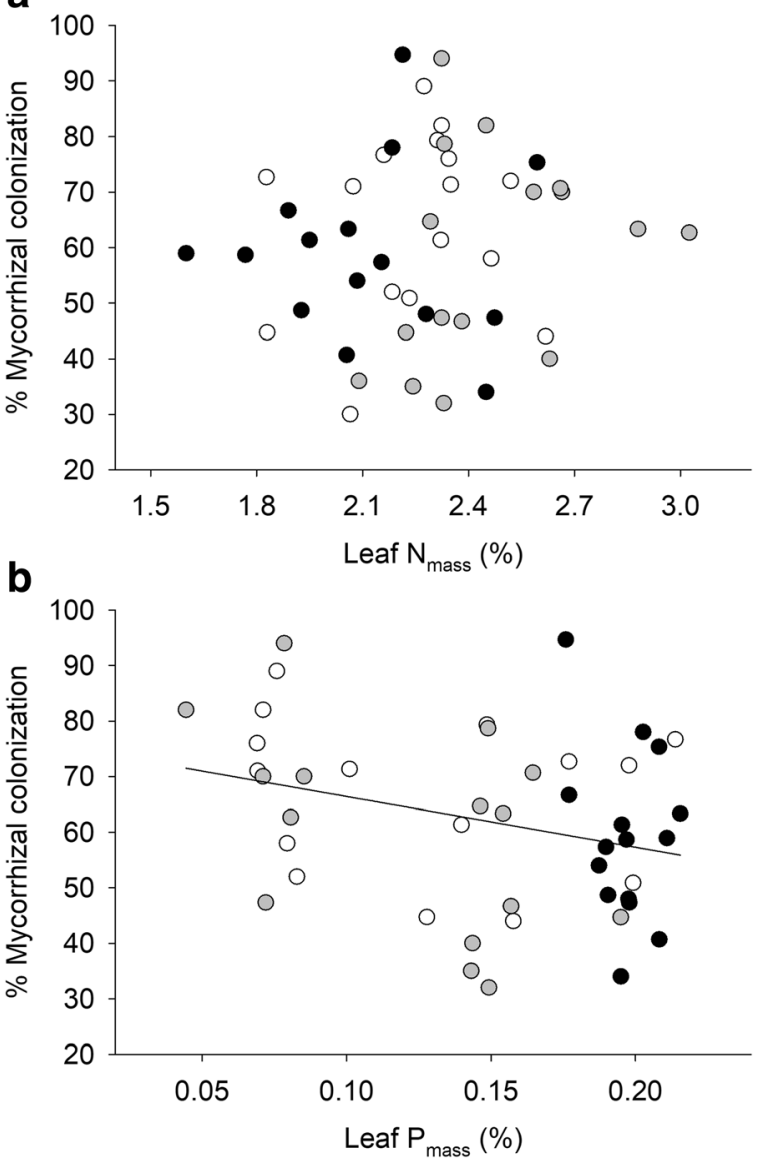

Fig. 4 Differences in percent AM mycorrhizal colonization of roots with leaf nitrogen concentration per unit mass $\left(\mathrm{N}_{\text {mass }} ;(\right.$ a)) and leaf phosphorus concentration per unit mass $\left(\mathrm{P}_{\text {mass }}\right.$; (b)) of Philodendron fragrantissimum within unfertilized, control plots (white circles) and plots fertilized with nitrogen (gray circles) and phosphorus (black circles) in the Gigante Fertilization Project in central Panama. The solid line denotes the significant correlation $(r=-0.30, P=0.05)$

We found that root architecture was influenced more by $\mathrm{P}$ - than $\mathrm{N}$-fertilization. Philodendron growing in the $\mathrm{P}$ addition treatment had greater root branching and a greater proportion of fine roots than in the control. In Hawaiian montane forests and Amazonian lowland forests, the availability of $\mathrm{P}$ had a larger effect on root dynamics than did the availability of N (Cuevas and Medina 1988; Ostertag 2001). In the GFP plots in our study, $\mathrm{P}$ is predominantly in its immobile form of $\mathrm{PO}_{4}{ }^{3-}$ (Yavitt et al. 2009). Thus, an increase in uptake rates and root growth and branching, particularly of fine roots, would increase $\mathrm{P}$ acquisition (Drew 1975; Hodge 2004) and could explain the higher leaf $\mathrm{P}$ concentrations of Philodendron in the Pfertilized plots. Our results are contrary to what was found at the GFP as NP addition and $\mathrm{K}$ addition reduced standing fine root biomass in one study (Wurzburger and Wright 2015) and $\mathrm{K}$ addition reduced biomass and increased turnover of fine roots in another study (Yavitt et al. 2011). The increase in fine roots with $P$ addition in our study could indicate that $\mathrm{P}$-addition did not mitigate $\mathrm{P}$ limitation for Philodendron, that the roots in the $\mathrm{P}$ addition plots are short-lived and maximize resource acquisition (i.e., have low tissue density; Wurzburger and Wright 2015), or that other factors, such as the availability of water, influence root structure more than nutrients as suggested by Wurzburger and Wright (2015). Root structure was not influenced by $\mathrm{N}$ addition, but Philodendron leaf $\mathrm{N}$ content was higher in the $\mathrm{N}$-addition treatment. $\mathrm{N}$ is predominantly in its oxidized and mobile form of $\mathrm{NO}_{3}{ }^{-}$in these tropical soils (Yavitt et al. 2009). The most efficient $\mathrm{N}$-acquisition strategy for plants in $\mathrm{NO}_{3}{ }^{-}$-dominated soils is to maintain a strong diffusional gradient towards the root system by increasing root uptake of $\mathrm{NO}_{3}{ }^{-}$per unit root length rather than increasing root growth, which is more costly (Marschner 2012). It appears that the nutrient acquisition strategy of Philodendron in this study varied with soil conditions in a way that would increase nutrient acquisition but minimize energy costs.

We found that Philodendron plants with higher leaf $\mathrm{P}$ concentrations had lower degrees of mycorrhizal colonization. This is contrary to what was found for fine roots across the GFP, which showed a modest increase in mycorrhizal colonization of $8 \%$ with P fertilization (Wurzburger and Wright 2015). Wurzburger and Wright (2015) were surprised by the increase in mycorrhizal colonization with $\mathrm{P}$ fertilization because $\mathrm{P}$ addition has decreased mycorrhizal colonization across many sites (Treseder 2004), and suggest that fertilization may have shifted the fungal community from symbiotic to parasitic. Our results are similar to what was found in seven of the most common tree species at the GFP where P addition reduced mycorrhizal colonization of their roots (Sheldrake et al. 2017). It is also similar to what was found for lianas; lianas invest more in root branching and have lower mycorrhizal colonization than trees indicating that lianas may be less reliant on mycorrhizae for resource acquisition than trees (Collins et al. 2016). Like lianas, Philodendron may suppress mycorrhizal colonization in order to invest more energy in fine root production to acquire $\mathrm{P}$. The degree of mycorrhizal colonization with $\mathrm{P}$ addition might have been reduced because mycorrhizal abundance decreased. Across many ecosystems and in the GFP, experimental 
phosphorus addition reduced the abundance of AM fungi (Treseder 2004; Sheldrake et al. 2017). We found no relationship between the degree of mycorrhizal colonization and leaf $\mathrm{N}$ concentration and no difference in mycorrhizal colonization between $\mathrm{N}$-addition plots and control plots. Philodendron likely does not associate with mycorrhizae to increase nutrient acquisition of $\mathrm{N}$ or is not N-limited and doesn't require mycorrhizae to acquire $\mathrm{N}$.

The higher leaf $\mathrm{P}$ concentration, smaller $\mathrm{C}: \mathrm{P}$ and $\mathrm{N}: \mathrm{P}$, and greater root branching in the P-addition treatment relative to the control suggests that Philodendron has the potential to be P-limited in these soils. The increase in leaf $\mathrm{P}$ concentration could also indicate luxury consumption (Chapin III 1980); thus future research could examine whether the higher leaf $\mathrm{P}$ concentration in Philodendron results in higher growth or reproduction rates. Although leaf $\mathrm{N}$ concentration was higher in the $\mathrm{N}$-addition treatment relative to the control, Philodendron does not appear to be as limited by $\mathrm{N}$ as it is by $\mathrm{P}$ given that the $\mathrm{C}: \mathrm{N}$ in plant leaves was not significantly different between the $\mathrm{N}$-addition treatment and the control. The large and consistent response by tropical plants to Pfertilization including Philodendron and those at the GFP site (see Methods: Study site) suggests that P may limit plant productivity at this site as suggested in previous studies (Wright et al. 2011; Santiago et al. 2012).

The difference in leaf $\mathrm{N}$ concentration in $\mathrm{N}$-addition plots compared to control plots found in this study $(+10 \%)$ was comparable to that of tropical tree seedlings $(11 \%$, Santiago et al. 2012) but the increase in the leaf $P$ concentration in our study (41\%) was much higher than in tropical tree seedlings (16\%, Santiago et al. 2012). The larger response in Philodendron relative to tropical trees may be due to differences in growth form. Unlike trees, nomadic vines don't invest much energy in supporting structures (Bigelow 1993). In this way, they are more like lianas, which maximize growth by investing in both above- and below-ground structures for resource acquisition at the expense of supporting structures (Collins et al. 2016). The increased investment by lianas to resource acquisition structures relative to support structures has resulted in lianas outperforming trees in various scenarios. For example, in forest gaps, lianas can limit tree growth through belowground competition (Schnitzer et al. 2005; ToledoAceves and Swaine 2008), and liana seedlings can outperform tree seedlings in the understory regardless of soil nutrient status (Pasquini et al. 2015). Thus, given its similar strategy to lianas, Philodendron could have a higher growth rate with $\mathrm{P}$ addition and potentially has a greater efficiency at acquiring soil $\mathrm{P}$ than tree seedlings.

How fertilization may influence the growth rate or growth strategy of nomadic vines has yet to be tested but could be influenced by their host trees if their host trees had an increase in foliar nutrients or an increase in litter production, both of which were seen at the GFP (Wright et al. 2011; Sayer et al. 2012). An increase in foliar nutrients could increase leaching of those nutrients in throughfall or stemflow, which could increase nutrient supply to dependent plants, as seen for epiphyte communities in montane forest in Kauai (Benner and Vitousek 2007). The growth form of many aroids is such that they trap litter in their leaves (Benzing 1990). Thus, an increase in litter production and nutrients in that litter could increase the amount of nutrients available for dependent plants, such as lianas, epiphytes, and nomadic vines. If the increase in leaf $\mathrm{P}$ concentrations in Philodendron are indicative of increased growth rates and not solely luxury consumption, as seen in some epiphytes (Winkler and Zotz 2009), it could increase the rate at which nomadic vines find and grow up host trees.

In conclusion, we found that soil nutrient composition and status influenced the nutrient acquisition strategy of a nomadic vine in light-limiting conditions of the deeply shaded understory. Philodendron plants in the Paddition treatment exhibited an increase in root growth relative to the control with $28 \%$ more root tips/length, a decrease in mycorrhizal colonization, and an increase in leaf $\mathrm{P}$ concentration. The large influence of $\mathrm{P}$ fertilization suggests that, like many tropical plants, Philodendron has the potential to be P-limited. Our results support the findings found for other understory plants in tropical forests and suggest that nomadic vines have the potential to be limited by multiple nutrients while in the understory under severe light limitation (Bloom et al. 1985).

Acknowledgements The authors thank Mark Wagner for field support and data collection; Christina Wells for the use of her lab to conduct root mycorrhizal analyses as well as use of the WinRhizo program; and the Smithsonian Tropical Research Institute and Barro Colorado Island for logistical support. We thank G. Zotz and an anonymous reviewer for helpful comments and edits on previous versions of our manuscript. Funding for this research was provided by Clemson University and a Wade T. Batson award for field botany to CLW. Financial support for the Gigante Fertilization Project is provided by grants from the Andrew W. Mellon Foundation and the Smithsonian Scholarly Studies program. 


\section{References}

Arsenault JL, Pouleur S, Messier C, Guay R (1995) WinRhizo, a root measuring system with a unique overlap correction method. HortScience 30:906

Balcázar-Vargas MP, Peñuela-Mora MC, van Andel TR, Zuidema PA (2012) The quest for a suitable host: size distributions of host trees and secondary hemiepiphytes search strategy. Biotropica 44:19-26

Benner JW, Vitousek PM (2007) Development of a diverse epiphyte community in response to phosphorus fertilization. Ecol Lett 10:628-636

Benzing DH (1990) Vascular epiphytes. General biology and related biota. Cambridge University Press, Cambridge

Bigelow SW (1993) Leaf nutrients in relation to stature and life form in tropical rain forest. J Veg Sci 4:401-408. https://doi. org/10.2307/3235599

Bloom AJ, Chapin FS III, Mooney HA (1985) Resource limitation in plants - an economic analogy. Annu Rev Ecol Evol Syst 16:363-392

Burslem DFRP, Grubb PJ, Turner IM (1996) Responses to simulated drought and elevated nutrient supply among shadetolerant tree seedlings of lowland tropical forest in Singapore. Biotropica 28:636-648

Chapin FS III (1980) The mineral nutrition of wild plants. Annu Rev Ecol Evol Syst 11:233-260

Chazdon RL, Fetcher N (1984) Light environments of tropical forests. In: Medina E, Mooney HA, Vásquez-Yanes C (eds) Physiol. Ecol. Plants Wet Trop. Dr. W. Junk Publishers, The Hague, pp 553-564

Clark RB, Zeto SK (2000) Mineral acquisition by arbuscular mycorrhizal plants. J Plant Nutr 23:867-902

Coley PD, Bryant JP, Chapin FS III (1985) Resource availability and plant antiherbivore defense. Science 230:895-900

Collins CG, Wright SJ, Wurzburger N (2016) Root and leaf traits reflect distinct resource acquisition strategies in tropical lianas and trees. Oecologia 180:1037-1047

Condit R, Engelbrecht BMJ, Pino D, Perez R, Turner BL (2013) Species distributions in responses to individual soil nutrients and seasonal drought across a community of tropical trees. Proc Natl Acad Sci 110:5064-5068

Coomes DA, Grubb PJ (2000) Impacts of root competition in forests and woodlands: a theoretical framework and review of experiments. Ecol Monogr 70:171-207

Cuevas E, Medina E (1988) Nutrient dynamics within Amazonian forests: fine root growth, nutrient availability, and leaf litter decomposition. Oecologia 76:222-235

D’Angelo E, Crutchfield J, Vandiviere M (2001) Rapid, sensitive, microscale determination of phosphate in water and soil. $\mathrm{J}$ Environ Qual 30:2206-2209

Drew MC (1975) Comparison of the effects of a localized supply of phosphate, nitrate, ammonium and potassium on the growth of the seminal root system, and the shoot, in barley. New Phytol 75:479-490

Drew MC, Saker LR (1978) Nutrient supply and the growth of the seminal root system in barley. III. Compensatory increases in growth of lateral roots, and in rates of phosphate uptake in response to a localised supply of phosphate. J Exp Bot 29: $435-451$
Dubuisson J-Y, Hennequin S, Bary S, Ebihara A, BoucheronDubuisson É (2011) Anatomical diversity and regressive evolution in the trichomanoid filmy ferns (Hymenophyllaceae): a phylogenetic approach. C R Biol 334:880-895

Eissenstat DM, Yanai RD (1997) The ecology of root lifespan. Adv Ecol Res 27:1-60

Elser J, Bracken MES, Cleland EE et al (2007) Global analysis of nitrogen and phosphorus limitation of primary producers in freshwater, marine and terrestrial ecosystems. Ecol Lett 10: $1135-1142$

Farley RA, Fitter AH (1999) The response of seven co-occuring woodland herbaceous perennials to localized nutrient-rich patches. J Ecol 87:849-859

Fitter AH (1985) Functional significance of root morphology and root system architecture. In: Fitter AH, Atkinson D, Read DJ, Usher MB (eds) Ecol. Interact. soil. Blackwell Scientific Publications, Oxford, pp 87-106

Fitter AH (1991) Costs and benefits of mycorrhizae: implications for functioning under natural conditions. Experientia 47:350-355

Fitter AH, Williamson L, Linkohr B, Leyser O (2002) Root system architecture determines fitness in an Arabidopsis mutant in competition for immobile phosphate ions but not for nitrate ions. Proc R Soc London B 269:2017-2022

Güsewell S (2004) N:P ratios in terrestrial plants: variation and functional significance. New Phytol 164:243-266

Hättenschwiler S (2002) Liana seedling growth in response to fertilisation in a neotropical forest understorey. Basic Appl Ecol 3:135-143

Hodge A (2004) The plastic plant: root responses to heterogeneous supplies of nutrients. New Phytol 162:9-24

Holdridge LR, Budowski G (1956) Report on an ecological survey of the Republic of Panama. Caribb For 17:92-110

Jackson RB, Manwaring JH, Caldwell MM (1990) Rapid physiological adjustment of roots to localized soil enrichment. Nature 344:58-60

Jones JB, Case BW (1996) Soil testing and plant analysis no. 3. In: Sparks DL (ed) Methods soil anal. Part 3 Chem. Methods. Soil Science Society of America, Madison, pp 389-415

Kaspari M, Garcia MN, Harms KE, Santana M, Wright SJ, Yavitt JB (2008) Multiple nutrients limit litterfall and decomposition in a tropical forest. Ecol Lett 11:35-43

Koske RE, Gemma JN (1989) A modified procedure for staining roots to detect VA mycorrhizas. Mycol Res 92:486-505

Lambers H, Raven JA, Shaver GR, Smith SE (2008) Plant nutrient-acquisition strategies change with soil age. Trends Ecol Evol 23:95-103

LeBauer DS, Treseder KK (2008) Nitrogen limitation of net primary productivity in terrestrial ecosystems is globally distributed. Ecology 89:371-379

Marschner P (2012) Mineral nutrition of wild plants, 3rd edn. Academic Press, San Diego

Marschner H, Dell B (1994) Nutrient uptake in mycorrhizal symbiosis. Plant Soil 159:89-102

Mayor JR, Wright SJ, Turner BL (2014) Species-specific responses of foliar nutrients to long-term nitrogen and phosphorus additions in a lowland tropical forest. J Ecol 102:3644. https://doi.org/10.1111/1365-2745.12190

McCormack ML, Dickie IA, Eissenstat DM et al (2015) Redefining fine roots improves understanding of belowground contributions to terrestrial biosphere processes. New Phytol 207:505-518 
McGonigle TP, Miller MH, Evans DG et al (1990) A new method which gives an objective measure of colonization of roots by vesicular-arbuscular mycorrhizal fungi. New Phytol 115: 495-501

Mirabello MJ, Yavitt JB, Garcia M, Harms KE, Turner BL, Wright SJ (2013) Soil phosphorus responses to chronic nutrient fertilisation and seasonal drought in a humid lowland forest, Panama. Soil Res 51:215-221

Mirmanto E, Proctor J, Green J, Nagy L, Suriantata (1999) Effects of nitrogen and phosphorus fertilization in a lowland evergreen rainforest. Philos Trans R Soc Lond Ser B Biol Sci 354: 1825-1829. https://doi.org/10.1098/rstb.1999.0524

Mo Q, Zou B, Li Y et al (2015) Response of plant nutrient stoichiometry to fertilization varied with plant tissues in a tropical forest. Sci Rep 5:1-12

Moffett MW (2000) What's "up"? A critical look at the basic terms of canopy biology. Biotropica 32:569-596

Nielsen SL, Enríquez S, Duarte CM, Sand-Jensen K (1996) Scaling maximum growth rates across photosynthetic organisms. Funct Ecol 10:167-175

Ostertag R (2001) Effects of nitrogen and phosphorus availability on fine-root dynamics in Hawaiian montane forests. Ecology 82:485-499

Pasquini SC, Wright SJ, Santiago LS (2015) Lianas always outperform tree seedlings regardless of soil nutrients: results from a long-term fertilization experiment. Ecology 96: 1866-1876

Putz FE, Holbrook NM (1986) Notes on the natural history of hemiepiphytes. Selbyana 9:61-69

R Development Core Team (2009) R: A language and environment for statistical computing

Robinson D, Rorison IH (1983) A comparison of the responses of Lolium perenne L., Holcus lanatus L., and Deschampsia flexuosa (L.) Trin. To a localized supply of nitrogen. New Phytol 94:263-273

Santiago LS, Wright SJ, Harms KE, Yavitt JB, Korine C, Garcia MN, Turner BL (2012) Tropical tree seedling growth responses to nitrogen, phosphorus and potassium addition. $\mathrm{J}$ Ecol 100:309-316

Sayer EJ, Wright SJ, Tanner EVJ et al (2012) Variable responses of lowland tropical forest nutrient status to fertilization and litter manipulation. Ecosystems 15:387-400

Schnitzer SA, Bongers F (2002) The ecology of lianas and their role in forests. Trends Ecol Evol 17:223-230

Schnitzer SA, Kuzee ME, Bongers F (2005) Disentangling aboveand below-ground competition between lianas and trees in a tropical forest. J Ecol 93:1115-1125

Sheldrake M, Rosenstock NP, Revillini D, Olsson PA, Wright SJ, Turner BL (2017) A phosphorus threshold for mycoheterotrophic plants in tropical forests. Proc R Soc London B 284:20162093

Soil Staff Survey (1999) Soil taxonomy: a basic system of soil classification for making and interpreting soil surveys

Stewart RH, Stewart JL, Woodring WP (1980) Geologic map of the Panama Canal and vicinity, Republic of Panama. U.S. Geol. Surv. Misc. Investig. Ser. Map I-232

Strong DR, Ray TS (1975) Host tree location behavior of a tropical vine (Monstera gigantea) by skototropism. Science 190: 804-806

Tanner EVJ, Kapos V, Franco W (1992) Nitrogen and phosphorus fertilization effects on Venezuelan montane forest trunk growth and litterfall. Ecology 73:78-86. https://doi. org/10.2307/1938722

Tibbet M (2000) Roots, foraging and the exploitation of soil nutrient patches: the role of mycorrhizal symbioses. Funct Ecol 14:397-399

Toledo-Aceves T, Swaine MD (2008) Above- and below-ground competition between the liana Acacia kamerunensis and tree seedlings in contrasting light environments. Plant Ecol 196: 233-244

Treseder KK (2004) A meta-analysis of mycorrhizal responses to nitrogen, phosphorus, and atmospheric $\mathrm{CO} 2$ in field studies. New Phytol 164:347-355. https://doi.org/10.1111/j.14698137.2004.01159.x

Tripler CW, Kaushal SS, Likens GE, Walter MT (2006) Patterns in potassium dynamics in forest ecosystems. Ecol Lett 9:451-466

Turner BL, Yavitt JB, Harms KE, Garcia MN, Romero TE, Wright SJ (2013) Seasonal changes and treatment effects on soil inorganic nutrients following a decade of fertilization in a lowland tropical forest. Soil Sci Soc Am J 77:1357-1369

van Vuuren MMI, Robinson D, Griffiths BS (1996) Nutrient inflow and root proliferation during the exploitation of a temporally and spatially discrete source of nitrogen in soil. Plant Soil 178:185-192

Vitousek PM, Farrington H (1997) Nutrient limitation and soil development: experimental test of a biogeochemical theory. Biogeochemistry 37:63-75

Wanek W, Zotz G (2011) Are vascular epiphytes nitrogen or phosphorus limited? A study of plant $15 \mathrm{~N}$ fractionation and foliar N:P stoichiometry with the tank bromeliad Vriesea sanguinolenta. New Phytol 192:462-470

Wang L, Mou PP, Jones RH (2006) Nutrient foraging via physiological and morphological plasticity in three plant species. Can J For Res 36:164-173

Williams-Linera G, Lawton RO (1995) The ecology of hemiepiphytes in forest canopies. In: Lowman MD, Nadkarni NM (eds) For. Canopies. Academic Press, New York, New York, pp 255-283

Winkler U, Zotz G (2009) Highly efficient uptake of phosphorus in epiphytic bromeliads. Ann Bot 103:477-484

Woods CL, DeWalt SJ (2013) The conservation value of secondary forests for vascular epiphytes in Central Panama. Biotropica 45:119-127

Wright SJ, Yavitt JB, Wurzburger N, Turner BL, Tanner EVJ, Sayer EJ, Santiago LS, Kaspari M, Hedin LO, Harms KE, Garcia MN, Corre MD (2011) Potassium, phosphorus, or nitrogen limit root allocation, tree growth, or litter production in a lowland tropical forest. Ecology 92:1616-1625

Wright SJ, Turner BL, Yavitt JB, Harms KE, Kaspari M, Tanner EVJ, Bujan J, Griffin EA, Mayor JR, Pasquini SC, Sheldrake M, Garcia MN (2018) Plant responses to fertilization experiments in lowland, species-rich, tropical forests. Ecology 99: 1129-1138. https://doi.org/10.1002/ecy.2193

Wurzburger N, Wright SJ (2015) Fine-root responses to fertilization reveal multiple nutrient limitation in a lowland tropical forest. Ecology 96:2137-2146

Yavitt JB, Wright SJ, Wieder RK (2004) Seasonal drought and dry-season irrigation influence leaf-litter nutrients and soil enzymes in a moist, lowland forest in Panama. Austral Ecol 29:177-188

Yavitt JB, Harms KE, Garcia MN, Wright SJ, He F, Mirabello MJ (2009) Spatial heterogeneity of soil chemical properties in a 
lowland tropical moist forest, Panama. Aust J Soil Res 47: 674-687

Yavitt JB, Harms KE, Garcia MN et al (2011) Soil fertility and fine root dynamics in response to 4 years of nutrient $(\mathrm{N}, \mathrm{P}, \mathrm{K})$ fertilization in a lowland tropical moist forest, Panama. Austral Ecol 36:433-445
Zhu G, Yoh M, Gilliam FS et al (2013) Nutrient limitation in three lowland tropical forests in southern China receiving high nitrogen deposition: insights from the fine root responses to nutrient additions. PLoS One 8:e82661

Zotz G (2013) "Hemiepiphyte": confusing term and its history. Ann Bot 111:1015-1020 